\title{
EFFECTS OF NEONATAL GAMMA IRRADIATION ON HORMONE PRODUCTION AND SPERMATOGENESIS IN THE TESTIS OF THE ADULT PIG
}

\author{
B. H. ERICKSON \\ Agricultural Research Laboratory of The University of Tennessee, \\ Oak Ridge, Tennessee, U.S.A.
}

(Received 18th December 1963)

\begin{abstract}
Summary. The morphogenesis of the Leydig cells and germ cells of the pig during the first 130 days after birth is described in relation to estimates of cellular radiosensitivity. Boars aged 1 to 30 days were exposed totally to $200 \mathrm{r}$ of gamma rays and the effects on the Leydig cells and germ cells were determined before and after puberty. The number of gonocytes (primitive germ cells) declined to $10 \%$ of the control values by Day 30 after irradiation, but at Day 60 some recovery was evident. Postpubertally, an average of $23 \%$ of the seminiferous tubules seen in transverse section in the irradiated testes exhibited radiation damage which was presumably permanent. Average sperm production was $47 \%$ of the control value. Increased numbers of crenated nuclei and a delay in morphogenesis were noted among the Leydig cells before puberty. Urinary steroid output of the irradiated boars equalled or exceeded that of the non-irradiated boars and it is assumed that $200 \mathrm{r}$ of gamma rays effected no permanent damage among the Leydig cells.
\end{abstract}

\section{INTRODUCTION}

Gamma irradiation has been shown to be effective in diminishing both the germinal (Shaver, 1953; Harding, 1961; Hughes, 1962) and hormonal (Wall, 1961) capacities of the neonatal rat testis. Hughes (1962) found that from birth to the 3rd day postpartum $150 \mathrm{r}$ of X-irradiation delivered to the testis of the rat would virtually destroy the germ-cell population; but from the 3 rd to the 4 th postnatal days germ-cell radiosensitivity diminished sharply. The drop in germ-cell radiosensitivity at Day 4 was correlated with an increase in mitotic activity among the primitive germ cells (gonocytes) and the appearance of definitive spermatogonia. The gonocyte population of the bovine has been found to be less radiosensitive than its counterpart in the rat (Erickson, 1964) but it follows a similar although more protracted pattern of changes in radiosensitivity; the period of greatest germ-cell sensitivity lies between 1 and 70 days postpartum. It was less sensitive from Day 80 to Day 105, when increasing numbers of gonocytes assumed the spermatogonial character.

Wall (1961) determined the effects of X-irradiation on the differentiating 
Leydig cell of the neonatal rat testis. Testes aged 3 to 36 days were exposed to 400,800 and $1200 \mathrm{r}$. Weights of the accessory sex glands and interstitial cell volume were both significantly depressed by all dose levels and as age increased the effect was decreased.

In this study the response of the neonatal pig testis to a single total-body exposure of gamma irradiation was determined, and changes in the nonirradiated germ cells and Leydig cells are described.

\title{
MATERIALS AND METHODS
}

\begin{abstract}
ANIMALS
Males from nine litters of pigs of mixed breeding were used. Five of the litters included three males and the other four each included at least four males. Two boars from each litter were irradiated at 1, 4,6,12,18,20,22, 25 or 30 days of age and the others served as controls. To determine the more immediate effects of irradiation on the germ cells, one boar from each age group was orchidectomized $10,20,30,40$ or 60 days after irradiation (one pig at 60 days and two at all other intervals). The remaining irradiated boar of each pair was kept for semen and urinary steroid analyses when it was 14 months old. Four non-irradiated boars (one from each of the litters with four males) served as controls. The remaining non-irradiated boars (one from each litter), together with additional boars of similar genetic composition, provided testicular tissue which was used to follow the developmental course of the germ cells and Leydig cells during the first 130 days postnatal life (two boars at each 10-day interval).
\end{abstract}

\section{IRRADIATIONS}

The boar was restrained over calibrated reference points and exposed to a whole-body dose of $200 \mathrm{r}$ (measured in air at skin level) of gamma rays (cobalt60 ) at $4.0 \mathrm{r} / \mathrm{min}$.

\section{HISTOLOGICAL ANALYSIS}

At castration, the testes were stripped free of their adnexa and weighed. Transverse slices were taken from the poles and centre of each testis and fixed in Zenker-formol. Sections were cut at $5 \mu$ and stained with haematoxylin and eosin. In tissues excised from prepubertal animals, 600 seminiferous tubule or sex-cord cross-sections were scored per animal (300 per testis). Total numbers of gonocytes or type-A spermatogonia (Clermont \& Perry, 1957) and of sections with no germinal elements (sterile) were recorded. Mitotic figures (metaphase and anaphase) of both gonocytes and 'supporting cells' (primitive Sertoli cells, Glermont \& Perry, 1957) were counted in the prespermatogenic control series. Gonocyte mitoses were distinguished from supporting cell mitoses mainly on the basis of measurements of metaphase equatorial plates ( 7 to $8 \mu$ for gonocytes and 5 to $6 \mu$ for supporting cells) and the greater chromosomal mass of the former. Twelve hundred tubule cross-sections were evaluated in each of the 15-month-old boars. Tubules were classified as normal (all spermatogenic 
generations present), prepubescent (spermatogonia and spermatocytes present in reduced numbers, but no spermatids) or sterile (complete absence of germinal elements). The bulbo-urethral glands and the seminal vesicles, with secretions intact, were weighed at slaughter.

Semen collection and evaluation followed the methods of Pace, Murphree \& Hupp (1961). Semen volume, sperm concentration, motility, and morphology were the criteria considered.

\section{STEROID DETERMINATIONS}

To facilitate urine collection, boars were confined in metabolism crates. The product of the first urination was discarded and the time of its occurrence was noted. From this point three successive 24-hr urine samples were collected from each boar. Conjugated steroids were freed through the standard procedure of boiling the urine with concentrated hydrochloric acid $(100 \mathrm{ml}$ urine with $15 \mathrm{ml}$ $\mathrm{HCl}$, added after boiling was started) under reflux for $10 \mathrm{~min}$ (Smith \& Smith, 1935). Total steroids were recovered from the reflux mixture and fractionated into neutral (androgenic) and phenolic (oestrogenic) parts after the method of Engel (1950). Neutral 17-ketosteroids were quantified through the Zimmerman chromogenic reaction, as modified by Nathanson \& Wilson (1943), and a Klett photolometer. The Kober reaction as modified by Stevenson \& Marrian (1947) and the Klett photolometer were employed in the quantification of the phenolic steroid fraction. Androsterone and oestrone served as standards for the neutral and phenolic steroids, respectively.

\section{RESULTS}

POSTNATAL MORPHOGENESIS OF THE NON-IRRADIATED MALE GERM CELL

The sex cord (primitive seminiferous tubule), as depicted in Pl. 1, Fig. 1, is composed of two distinct cell types. These are: (1) the supporting cells, which form a continuous layer at the periphery of the cord and which will constitute the Sertoli cells of the postpubertal testis, and (2) the gonocytes, precursors of the spermatogonia, which occupy a position central to the supporting cells.

Mitotic activity was at a high level among both the gonocytes and supporting cells for the first 10 days after birth. These mitoses are reflected in high germcell counts and an approximately four-fold increase in testicular weight (Table 1). Mitosis continued at a high level among the supporting cells to Day 30 postnatal. It then diminished sharply and was apparently discontinued entirely in testes aged 120 days. From a high of ninety-five at Day 10, numbers of gonocyte mitotic figures declined to $32 \pm 3$ during the interval from 20 to 70 days postnatal. The decline in germ-cell numbers and increase in number of sterile cord cross-sections also seen during this interval were probably consequences of both sex-cord growth with resultant germ-cell dispersal and the apparent decline in germ-cell mitotic activity. The number of germinal mitotic figures seen at 80 days was twice that seen at 70 days. This increase paralleled the first appearance of type-A spermatogonia and an abrupt rise in total germ-cell numbers. 
Spermatocytes were present in the testes of boars aged 100 days and spermatids at an age of 130 days, when the supporting cells assumed the Sertoli character.

Testis weight more than doubled between 10 and 30 days in association with the high mitotic rate among the supporting cells, but further weight changes were small until the initiation of spermatogenesis at Day 80. From this point testis weight fluctuated widely, depending on the degree of spermatogenic activity. Spermatocytes were present in the majority of cross-sections of the seminiferous tubules at 100 days, but in few of them at 110 and 120 days, when testis weight was far below that reached at 100 days.

MORPHOGENESIS OF THE LEYDIG GELL OF THE PIG

In terms of comparative cell size the Leydig cells were small from Days 2 to 10 ,

TABLE 1

POSTNATAL MORPHOGENESIS OF THE NON-IRRADIATED GERM CELL OF THE BOAR*

\begin{tabular}{|c|c|c|c|c|c|c|c|}
\hline \multirow{2}{*}{$\begin{array}{c}\text { Age } \\
\text { (days) }\end{array}$} & \multirow{2}{*}{$\begin{array}{l}\text { Combined } \dagger \\
\text { testis wt }(\mathrm{g})\end{array}$} & \multicolumn{2}{|c|}{ No. mitotic figures $\ddagger$} & \multirow{2}{*}{$\begin{array}{c}\text { No. necrotic } \\
\text { gonocytes }\end{array}$} & \multirow{2}{*}{$\begin{array}{c}\text { No. germ } \\
\text { cells }\end{array}$} & \multirow{2}{*}{$\begin{array}{c}\text { No. type-A } \\
\text { spermatogonia }\end{array}$} & \multirow{2}{*}{$\begin{array}{c}\text { No. sterile } \\
\text { tubule } \\
\text { cross-sections }\end{array}$} \\
\hline & & Germ cells & Support cells & & & & \\
\hline $\begin{array}{r}2 \\
10 \\
20 \\
30 \\
40 \\
50 \\
60 \\
70 \\
80 \\
90 \\
100 \\
110 \\
120 \\
130\end{array}$ & $\begin{array}{r}0.4 \\
3.2 \\
4.9 \\
10.5 \\
12.7 \\
12.6 \\
13.6 \\
11.9 \\
17.2 \\
22.3 \\
73.4 \\
17.7 \\
21.1 \\
72.3\end{array}$ & $\begin{array}{r}54 \\
95 \\
30 \\
38 \\
35 \\
26 \\
38 \\
26 \\
57 \\
98 \\
84 \\
66 \\
93 \\
163\end{array}$ & $\begin{array}{r}36 \\
84 \\
60 \\
59 \\
25 \\
13 \\
16 \\
14 \\
6 \\
9 \\
3 \\
3 \\
0 \\
0\end{array}$ & $\begin{array}{r}3 \\
0 \\
0 \\
2 \\
9 \\
33 \\
18 \\
35 \\
18 \\
24 \\
102 \\
29 \\
60 \\
42\end{array}$ & $\begin{array}{r}1920 \\
1380 \\
1125 \\
948 \\
1164 \\
1209 \\
1301 \\
1013 \\
1712 \\
1653 \\
1809 \\
2304 \\
2586 \\
2055\end{array}$ & $\begin{array}{r}0 \\
0 \\
0 \\
0 \\
0 \\
0 \\
0 \\
0 \\
171 \\
303 \\
1078 \\
279 \\
972 \\
1892\end{array}$ & $\begin{array}{r}2 \\
13 \\
48 \\
102 \\
63 \\
36 \\
24 \\
81 \\
7 \\
4 \\
0 \\
0 \\
0 \\
0\end{array}$ \\
\hline
\end{tabular}

* Six hundred tubular cross-sections were scored per animal; 300 per testis.

† All numbers are averages obtained from two animals.

$\ddagger$ Includes only metaphase and anaphase figures.

large from Days 20 to 60, small from Days 70 to 90 and thenceforth large (definitive Leydig cells). The nucleus of the primitive 'small' cell was 5 to $6 \mu$ in diameter, its nucleolus was obscured by precipitated chromatin, and two to three basophilic bodies were present in the nucleoplasm. The nuclear : cytoplasmic ratio was low (PI. 1, Fig. 1). In addition to an increase in cytoplasmic volume and nuclear diameter ( 5 to $6 \mu$ for the small cell versus 7 to $8 \mu$ for the large cell), the primitive 'large' cell was characterized by a prominent nucleolus and less basophilic nucleoplasm (Pl. 1, Fig. 2). There was no difference between the 'small' cells of the first and second orders. The nucleus of the 'large' cell of the second order, or definitive Leydig cell, was 6 to $7 \mu$ in diameter, with a prominent acidophilic nucleolus bearing a small chromatin cap. Most of the nuclear chromatin was deposited uniformly at the nuclear membrane, leaving the nucleoplasm free from all but an occasional large chromatin deposit (Pl. 1, 


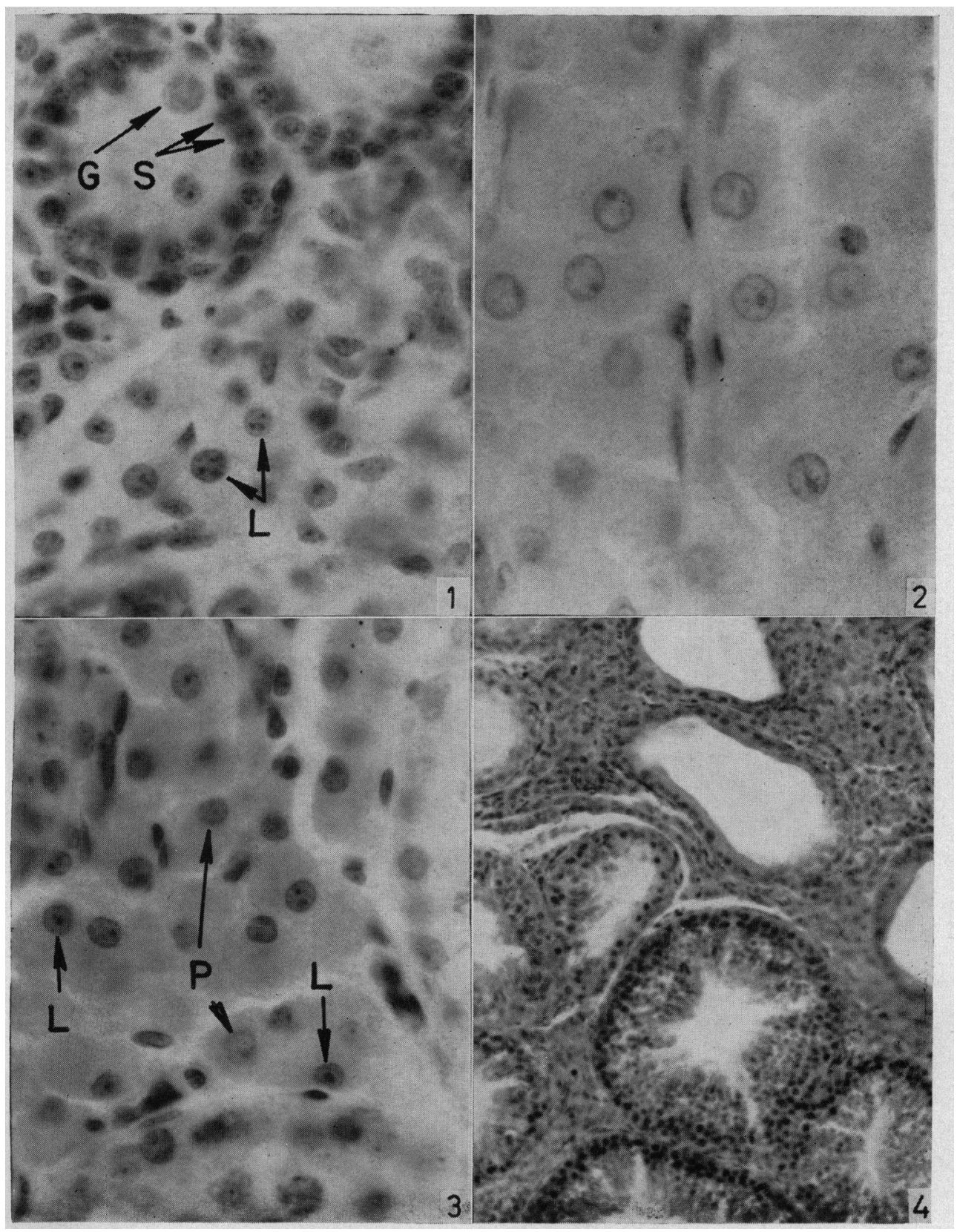

Fig. 1. Cellular composition of the 2 day postnatal pig testis. G-primitive germ cell. $\mathrm{S}$ - supporting cells (primitive Sertoli cell) of sex cord or primitive seminiferous tubule. L-primitive Leydig cells of 'small' and 'large' types. $\times 770$.

Fig. 2. Leydig cells of pig testis aged 20 days. Note the large nuclear and cytoplasmic volumes. $\times 770$.

Fig. 3. Definitive (L) and primitive (P) Leydig cells of the pig testis aged 130 days. Note intense acidophilia and chromatin cap of the nucleoli of the dcfinitive cells. Note also meiotic figures within the seminifcrous tubule at the bottom of the figure. $\times 770$.

FIG. 4. Neonatally irradiated pig testis aged 15 months at castration. Note adjacent sterile and fertile seminiferous tubule cross-sections. $\times 350$.

(Facing p. 94) 
Fig. 3). Throughout its postnatal metamorphosis the limiting membrane of the Leydig cell was distinct and its configuration varied from oval to polyhedral (Pl. I, Fig. 2). Mitoses were rarely seen before Day 90, but from 90 to 130 days a single transverse section not uncommonly included three or four mitotic figures.

In testes of 2 to 10 days the Leydig cells were principally of the small type, but a few primitive large cells were also present (Pl. 1, Fig. 1). In testes of 20 to 60 days the intertubular spaces were large and primitive large cells predominated. At 70 days of age the intertubular area was drastically reduced and atrophy of the large cells had apparently occurred, since the small cell again predominated. Primitive large cells were seen less frequently in older animals.

\section{TABLE 2}

RESPONSE OF THE EARLY POSTNATALLY IRRADIATED TESTIS OF THE BOAR TO $200 \mathrm{r}$ OF GAMMA RAYS AS DETERMINED THROUGH SEMEN AND HISTOLOGICAL ANALYSES AT 15 MONTHS OF AGE

\begin{tabular}{|c|c|c|c|c|c|c|c|}
\hline \multirow{2}{*}{$\begin{array}{l}\text { Boar } \\
\text { No. }\end{array}$} & \multirow{2}{*}{$\begin{array}{c}\text { Age at } \\
\text { irradiation } \\
\text { (days) }\end{array}$} & \multirow{2}{*}{$\begin{array}{l}\text { Total } \\
\text { testis } \\
w t(g)\end{array}$} & \multicolumn{3}{|c|}{ Tubule cross-sections" } & \multirow{2}{*}{$\begin{array}{c}\text { Semen vol.l } \\
\text { ejaculate }(m l)_{\ddagger}^{+}\end{array}$} & \multirow{2}{*}{$\begin{array}{c}\text { No. spermato zoal } \\
\text { ejaculate } \\
\left(\times 10^{9}\right)\end{array}$} \\
\hline & & & $\begin{array}{c}\text { No. pre- } \\
\text { pubescent }\end{array}$ & No. sterile & $\begin{array}{c}\text { Normal } \\
(\%)\end{array}$ & & \\
\hline $\begin{array}{l}8-10 \\
1-6 \\
8-11 \\
9-2 \\
4-11 \\
3-10 \\
6-3 \\
6-5 \\
3-4 \\
4-6 \\
2-7 \\
4-8\end{array}$ & $\begin{array}{c}\text { Control } \\
\text { Control } \\
\text { Control } \\
1 \\
4 \\
6 \\
12 \\
18 \\
20 \\
22 \\
25 \\
30\end{array}$ & $\begin{array}{r}662 \\
792 \\
850 \\
877 \\
787 \\
331 \\
557 \\
1020 \\
640 \\
611 \\
858 \\
980\end{array}$ & $\begin{array}{r}2 \\
5 \\
11 \\
229 \\
158 \\
42 \\
289 \\
156 \\
205 \\
90 \\
103 \\
30\end{array}$ & $\begin{array}{r}0 \\
0 \\
0 \\
305 \\
242 \\
76 \\
136 \\
73 \\
48 \\
88 \\
293 \\
57\end{array}$ & $\begin{array}{r}100 \\
100 \\
99 \\
56 \\
67 \\
91 \\
65 \\
82 \\
79 \\
84 \\
78 \\
93\end{array}$ & $\begin{array}{l}216 \\
180 \\
172 \\
255 \\
202 \\
132 \\
153 \\
182 \\
118 \\
151 \\
177\end{array}$ & $\begin{array}{c}31.2 \\
29.4 \\
55.8 \\
15.7 \\
16.8 \\
5.2 \\
9.9 \\
\stackrel{21.9}{5} \\
17.9 \\
32.8 \\
24.8\end{array}$ \\
\hline
\end{tabular}

- Twelve hundred seminiferous tubule cross-sections scored per animal (600 per testis).

$\dagger$ Tubule cross-sections that possessed spermatogonia and spermatocytes in reduced numbers, but were without spermatids.

$\ddagger$ Averages of ten ejaculates taken over a 5 week period.

$\S$ Failed to respond to semen collection techniques.

Definitive Leydig cells were first seen in testes of 100 days and by Day 130 the majority of the Leydig cells had assumed the definitive form.

\section{RADIORESPONSE OF THE NEONATAL GERM GELL}

In the testes of two animals examined 10 days after irradiation the total number of gonocytes in 600 tubule cross-sections had been reduced to $70 \%$ of the controls, and approximately one-quarter of the irradiated sex-cord cross-sections were without gonocytes (sterile). Twenty days after irradiation, gonocyte numbers had declined to $32 \%$ of the controls and two-thirds of the cord crosssections were sterile. In animals examined 30 and 40 days after irradiation, gonocyte numbers had fallen to $10 \%$ of the controls and five-sixths of cord 
cross-sections were sterile. Germ-cell renewal had apparently begun after 60 days, since gonocyte numbers in animals examined then had increased to $24 \%$ of control values and fewer than 500 of the 600 sex-cord cross-sections examined were sterile. Further observations were deferred to the postpubertal state.

When the boars were 15 months old, semen was collected from control and irradiated groups twice weekly for 5 weeks (Table 2). The average numbers of spermatozoa per ejaculate $\left(\times 10^{9}\right)$ were respectively $38.8 \pm 8.6$ and $18 \cdot 1 \pm 2.9$ for the control (three animals, Boar 3-7 died) and the irradiated (eight animals, one boar failed to respond to semen collection techniques) groups. The average volume of semen per ejaculate for the two groups was $189 \pm 14 \mathrm{ml}$ (non-irradiated) and $172 \pm 15 \mathrm{ml}$ (irradiated). Ejaculates from control boars were therefore $9 \%$ greater in volume and $43 \%$ greater in sperm content. The motility and morphology of spermatozoa from irradiated testes appeared to be normal.

Testis weight was extremely variable (Table 2), testes of control boars having an average combined weight of $768 \pm 58 \mathrm{~g}$ and those of irradiated boars $740 \pm 74 \mathrm{~g}$. The presumably permanent effects of radiation-induced gonocyte death were manifested histologically by sterile and prepubescent seminiferous tubules in the postpubertal testis, seen in cross-sections in Pl. 1, Fig. 4. Of the 1200 tubule cross-sections which were scored in the control material, none were sterile and an average of only six were of prepubescent type. In the irradiated testes, the corresponding averages were $146 \pm 31$ sterile and $145 \pm 29$ of prepubescent type. These data combined indicate that a $200 \mathrm{r}$ neonatal exposure of gamma irradiation reduces the functional germinal tissue of the postpubertal testis of the boar by an average of $23 \%$. Average body weights for the two groups when killed were $240 \pm 3 \mathrm{~kg}$ (control) and $234 \cdot 5 \pm 4 \mathrm{~kg}$ (irradiated).

\section{RADIORESPONSE OF THE DIFFERENTIATING LEYDIG GELL}

There was no evidence of irradiation-induced death among the Leydig cells in the testes of animals killed soon after irradiation, but there was an apparent increase in the number of crenated nuclei in tissues excised 10 or 20 days after irradiation, and a delay in Leydig cell morphogenesis. Primitive small Leydig cells rather than the primitive large cells predominated in testes aged 20 and 30 days. By 60 days after irradiation the Leydig cell picture had apparently returned to normal.

Determinations of $24 \mathrm{hr}$ excretion of urinary steroids were undertaken to detect possible permanent irradiation damage to the Leydig cell system (Table 3 ). The level of neutral 17-ketosteroids (androgens) was highest in the urine of irradiated boars: $118.9 \pm 6.1 \mathrm{mg}$ (nine boars) compared with $110.5 \pm 9.3 \mathrm{mg}$ (four boars) for the non-irradiated animals. Urinary phenolic steroid (oestrogen) levels were also higher in the irradiated group: $5 \cdot 36 \pm 0.44 \mathrm{mg}$ compared with $4.56 \pm 0.37 \mathrm{mg}$ for the control group. These differences were not statistically significant, although irradiated boars excreted an average of $7 \%$ more androgens and $15 \%$ more oestrogens during a $24 \mathrm{hr}$ period. Average weight of accessory glands (in grams) for non-irradiated and irradiated boars respectively were as follows: seminal vesicle, $528 \pm 24$ and $457 \pm 38$; bulbo-urethral gland, $262 \pm 56$ 
and $203 \pm 18$. In both instances the glands of non-irradiated animals were heavier, but these differences are assumed to lack significance owing to the low number of control boars.

\section{DISCUSSION}

\section{GERM CELLS}

Data obtained in this study showed that the primordial germ cell in the postnatal boar was sensitive to $200 \mathrm{r}$ of gamma rays, but this was insufficient to effect total sterility. In the rat, however, $150 \mathrm{r}$ of X-rays was a sterilizing dose for the first 3 postnatal days (Hughes, 1962). The primitive germ-cell popula-

TABLE 3

TWENTY-FOUR HOUR EXGRETION OF URINARY NEUTRAL 17-KETOSTEROIDS AND PHENOLIC STEROIDS BY THE EARLY POSTNATALLY IRRADIATED BOAR (200 r) AT 14 MONTHS OF AGE PLUS TESTIS AND ACCESSORY GLAND WEIGHTS

\begin{tabular}{|c|c|c|c|c|c|c|}
\hline \multirow{2}{*}{$\begin{array}{l}\text { Boar } \\
\text { No. }\end{array}$} & \multirow{2}{*}{$\begin{array}{c}\text { Age at } \\
\text { irradiation } \\
\text { (days) }\end{array}$} & \multirow{2}{*}{$\begin{array}{c}\text { Neutral (androgenic) } \\
17 \text {-ketosteroids }(\mathrm{mg})\end{array}$} & \multirow{2}{*}{$\begin{array}{l}\text { Phenolic (oestrogenic) } \\
\text { steroids }(\mathrm{mg})\end{array}$} & \multirow{2}{*}{$\begin{array}{c}\text { Total } \\
\text { testis } \\
w t(g)\end{array}$} & \multicolumn{2}{|c|}{ Accessory gland wt $(\mathrm{g})$} \\
\hline & & & & & $\begin{array}{l}\text { Seminal } \\
\text { vesicle }\end{array}$ & $\begin{array}{l}\text { Bulbo- } \\
\text { urethral }\end{array}$ \\
\hline $\begin{array}{l}8-10 \\
1-6 \\
8-11 \\
3-7 \\
9-2 \\
4-11 \\
3-10 \\
6-3 \\
6-5 \\
3-4 \\
4-6 \\
2-7 \\
4-8\end{array}$ & $\begin{array}{c}\text { Control } \\
\text { Control } \\
\text { Control } \\
\text { Control } \\
1 \\
4 \\
6 \\
12 \\
18 \\
20 \\
22 \\
25 \\
30\end{array}$ & 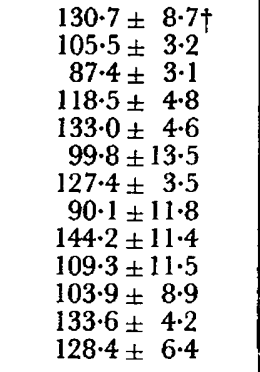 & $\begin{array}{l}5 \cdot 18 \pm 0.07 \\
4 \cdot 11 \pm 0.01 \\
3 \cdot 76 \pm 0.03 \\
5 \cdot 21 \pm 0.03 \\
7 \cdot 85 \pm 0.08 \\
4 \cdot 57 \pm 0.04 \\
3 \cdot 02 \pm 0.04 \\
5 \cdot 08 \pm 0.09 \\
6 \cdot 34 \pm 0 \cdot 11 \\
5 \cdot 31 \pm 0.09 \\
5 \cdot 16 \pm 0.03 \\
4.76 \pm 0.04 \\
6 \cdot 17 \pm 0.05\end{array}$ & $\begin{array}{c}662 \\
792 \\
850 \\
-7 \\
877 \\
787 \\
331 \\
557 \\
1020 \\
640 \\
611 \\
858 \\
980\end{array}$ & $\begin{array}{l}514 \\
573 \\
497 \\
-466 \\
427 \\
342 \\
375 \\
363 \\
391 \\
478 \\
595 \\
680\end{array}$ & $\begin{array}{l}219 \\
371 \\
196 \\
260 \\
292 \\
135 \\
224 \\
139 \\
215 \\
216 \\
178 \\
165\end{array}$ \\
\hline
\end{tabular}

* Average of determinations on three successive $24 \mathrm{hr}$ urine collections.

$\uparrow$ Standard error.

\$ Boar died prior to end of experiment.

tion of the bull as reported by Erickson (1964), responded to $200 \mathrm{r}$ of gamma rays in much the same manner as shown here for the boar. Erickson (1964) suggested that the differing radioresponses of the neonatal rat and bull gonocytes may reflect differences in their developmental histories. Glermont \& Perry (1957) reported that mitoses were rare or absent among the gonocytes of the rat before the appearance of the first definitive spermatogonia (4 days postnatal), and that gonocyte necrosis was a prominent feature of the neonatal rat testis. Conversely, bovine gonocytes were mitotically active before and after the appearance of the first type-A spermatogonia ( 70 days postnatal), and gonocyte loss was apparently due more to formation of type-A spermatogonia than to gonocyte necrosis (Erickson, 1964). Similarly, in the early postnatal boar testis there was much mitotic activity among the gonocytes and infrequent gonocyte necrosis (Table 1). Gonocyte mitosis assumes importance in terms of cellular 
radiosensitivity, since it has been demonstrated that a cell at interphase is more sensitive than one undergoing mitosis (Ord \& Stocken, 1956). Mitotic heterogeneity may therefore account for the lesser radiosusceptibility of the bull and boar gonocytes, although it may be due simply to greater tissue volume and germ-cell numbers.

Although the sperm production of the boars 15 months after irradiation suggests that gonocyte radiosensitivity decreases with age (Table 2), the histological analysis supports the conclusion that the sensitivity of the pig gonocyte does not change appreciably during the first 30 days after birth. Also, if as in the rat and the bull, postnatal germ-cell sensitivity remains high until the appearance of type-A spermatogonia, gonocyte sensitivity should remain high in the boar until approximately Day 80 (Table 1).

Studies in the artificial insemination of the gilt have shown that 2.5 (Stratman \& Self, 1960) to 3.5 (Wiggins, Gummer \& Casida, 1951) $\times 10^{9}$ spermatozoa are necessary for optimum fertility; hence, sperm production of all the irradiated boars, with the possible exception of Boar 3-10, is well above that needed for fecundity (Table 2). The low sperm output of Boar 3-10 was probably due to underdevelopment of the seminiferous tubule apparatus and not to irradiation damage, as the tubules were in the main qualitatively normal, but the number of tubule cross-sections per cross-section of testis was conspicuously below normal. This was reflected in the extremely low testis weight (Table 2). Steroid production and accessory gland weights for this boar were near or above the average of the group (Table 3), thus indicating that Leydig cell development was within the normal range. Supporting data for the semen production of non-irradiated boars are provided by the work of Stratman \& Self (1960). In their study three yearling boars of mixed breeding produced a combined average of $243 \times 10^{6}$ spermatozoa/ml (thirty-three ejaculates). The combined average for the non-irradiated boars in the present study was $210 \times 10^{6} \mathrm{spermatozoa} / \mathrm{ml}$ (thirty ejaculates).

\section{LEYDIG GELLS}

It is evident from the data presented in Table 3 that a $200 \mathrm{r}$ exposure of gamma irradiation did not permanently damage the differentiating Leydig cells. Huis in't Veld, Louwerens \& Reilingh (1961) reported a total neutral 17-ketosteroid value of $65 \mathrm{mg} / \mathrm{l}$ in the urine of the adult boar. Average $24 \mathrm{hr}$ urine output by the boars in the present study was 21 .; thus $65 \mathrm{mg} / \mathrm{l}$ closely approximates the data in Table 3 . The only evidence of irradiation effects of a permanent nature is provided by the work of Wall (1961). In his study of the early postnatal rat ( 3 to 36 days of age), $400 \mathrm{r}$ of X-irradiation applied to the metamorphosing Leydig cell population was shown to reduce its postpubertal functional capacity, as evidenced by suppressed accessory gland weights and decreased interstitial cell volume. A minimal effective dose was not established. The response of the postpubertal rat Leydig cell to X-irradiation differs markedly from the foregoing. Abbott (1959) has shown that 10,000 $\mathrm{r}$ of X-irradiation applied locally to the testis suppressed neither accessory gland weights nor libido of the exposed males up to 25 weeks after irradiation. The difference in radioresponses between 
differentiating and mature cells is perhaps due to the greater metabolic dependence of an immature cell on its nucleus (Wall, 1961).

The initial observation of definitive Leydig cells in the boar, and the stage at which they predominate over the primitive cell type, can both be directly related to changes in the germ-cell population. Spermatocytes and the first mature Leydig cells were first noted at Day 100 postnatal. At Day 130, spermatids were present in the seminiferous tubules and definitive Leydig cells were predominant in the intertubular spaces. Descriptions of the morphogenic sequence followed by the Leydig cells of other species agree in some measure with that given here for the pig. Roosen-Runge \& Anderson (1959) employed the PAS staining technique to follow the morphogenesis of the postnatal rat Leydig cell. During the 3rd postnatal week, these workers observed a pronounced increase in Leydig cell volume and initiation of cytoplasmic PAs affinity. The 4 th week was characterized by a marked increase in the number of PAs-positive droplets within the cytoplasm. The change at the 3rd week was correlated with the appearance of spermatocytes, and at the 4 th week with the appearance of spermatids. Hooker (1944) did not observe any change within the Leydig cells of the bull at puberty, but he did report seeing the first definitive Leydig cells in testes at 4 months. This finding also agrees closely in time with the beginning of meiotic changes among the bovine germ cells (Fossland \& Schultze, 1961).

Although the present study revealed that $200 \mathrm{r}$ of gamma irradiation retarded the morphogenesis of the Leydig cell of the boar, no lasting damage was observed. Thus, within the testis, germ-cell radiosusceptibility appears to be the factor which limits the fertility of the neonatally irradiated boar.

\section{ACKNOWLEDGMENTS}

This report is published with the permission of the Director of the University of Tennessee Agricultural Experiment Station, Knoxville.

The Agricultural Research Laboratory of the University of Tennessee is operated by the Tennessee Agricultural Experiment Station for the U.S. Atomic Energy Commission under Contract No. AT-40-1-GEN-242.

I am grateful to Dr E. W. Hupp and Mr J. F. Andrews for their assistance with the semen analysis. These investigators are now located at the Radiation Biology Laboratory, Texas A. and M. College and the Eli Lilly Co, respectively.

\section{REFERENCES}

Aввотт, G. R. (1959) The effect of X-irradiation on the secretory capacity of the testis. $\mathcal{F}$. Endocrinol. $19,33$.

Glermont, Y. \& Perry, B. (1957) Quantitative study of the cell population of the seminiferous tubules in immature rats. Amer. F. Anat. 100, 241.

Engel, L. L. (1950) The chemical estimation of steroid hormone metabolites. Recent Progr. Hormone Res. 5, 335.

ERICKson, B. H. (1964) Effects of gamma irradiation on the primitive germ cells of the prepubertal bovine testis. Int. J. rad. Biol. (In press).

Fossland, R. G. \& Schultze, A. B. (1961) A histological study of the postnatal development of the bovine testis. Agric. Exp. Sta. Univ. Nebr., Res. Bull. No. 199. 
Harding, L. K. (1961) The survival of germ cells after irradiation of the neonatal male rat. Int. J. rad. Biol. 3, 539.

Hooker, C. W. (1944) The postnatal history and function of the interstitial cells of the testis of the bull. Amer. 7. Anat. 74, 1.

Hughes, G. (1962) Radiosensitivity of male germ cells in neonatal rats. Int. 7. rad. Biol. 4, 511.

Huis in't Veld, L. G., Louwerens, B. \& Reilingh, W. (1961) Neutral 17-ketosteroids in porcine urine. Nature, Lond. 191, 175.

Nathanson, I. T. \& Wilson, H. (1943) Factors affecting colorimetric urinary 17-ketosteroid determinations. Endocrinology, 33, 189.

Ord, G. M. \& Stocken, L. A. (1956) The effects of X-and gamma-irradiation on nucleic acid metabolism in the rat in vivo and in vitro. Biochem. 7. 63, 3.

Pace, H. B., Murphree, R. L. \& Hupp. E. W. (1961) Effects of prenatal gamma irradiation on testicular morphology and function in swine. Amer. F. vet. Res. 22, 406.

Roosen-Runge, E. C. \& Anderson, D. (1959) The development of the interstitial cells in the testis of the albino rat. Acta anat. 37, 125.

Shaver, S. L. (1953) X-irradiation injury and repair in the germinal epithelium of male rats. II. Injury and repair in immature rats. Amer. 7. Anat. 92, 433.

Sмiтн, G. V. S. \& Sмiтh, O. W. (1935) The quantitative determination of urinary oestrin. Amer. 7 . Physiol. 112, 340.

Stevenson, M. F. \& Marrian, G. F. (1947) The determination of oestrogens in human pregnancy urine. A new method of correcting for the brown colour developed in the Kober reaction by nonestrogenic substances. Biochem. $7.41,507$.

Stratman, F. W. \& Self, H. L. (1960) Effect of semen volume and number of sperm on fertility and embryo survival in artificially inseminated gilts. 7. Anim. Sci. 19, 1081.

Wall, P. G. (1961) Effects of X-irradiation on differentiating Leydig cells of the immature rat. $\mathcal{F}$. Endocrin. 23, 291.

Wrggins, E. L., Grummer, R. H. \& Casida, L. E. (1951) Minimal volume of semen and number of sperm for fertility in artificial insemination in swine. J. Anim. Sci. 10, 138. 